\title{
Laboratory acquired brucellosis: a report of two cases
}

\section{Laboratuvar kaynaklı bruselloz: iki olgu sunumu}

\author{
Ibak GÖNEN'1, Onur KAYA 1 , Hamdi SÖZEN²
}

\section{ÖZET}

Bruselloz; Brucella türü bakterilerin neden olduğu, değișik organ ve sistemleri etkileyen ve ülkemizde halen endemik olan zoonotik bir enfeksiyon hastalığıdır. Enfekte hayvana temas veya enfekte hayvanlardan elde edilen pastorize edilmemiș süt ve süt ürünleri ile bulașırken, bu bakterilerle çalışan laboratuvar personeline de direkt temas ya da inhalasyon yolu ile bulașmaktadır. Bu nedenle hayvancılık yapanlar ve veterinerlerin yanında laboratuvar personeli de bruselloz açısından risk grubunda yer almaktadır. Dünyada laboratuvardan kazanılmış enfeksiyonlar arasında en sık karșılașılan enfeksiyon hastalığı brusellozdur. Bununla birlikte ülkemizde laboratuvar kaynaklı bruselloz olguları nadiren bildirilmiștir. Bu yazıda iki mikrobiyoloji laboratuvar çalıșanında meydana gelen ve laboratuvar ortamında bulașan bruselloz olguları sunulmuștur. Olguların ikisi de bayan olup; ateș, kas ve eklem ağrısı gibi șikayetlerle bașvurmuș ve fiziki muayenede ateș dıșında bir özellik saptanmamıștır. Hemogram ve biyokimyasal parameteleri normal sınırlar içerisinde olan her iki olgunun ortak özelliği yakın zamanda Brucella türü bakterilerle çalıșmış olmaları idi. Birinci olgu bașlangıçta viral enfeksiyon olarak değerlendirilmiș, tanısı yaklașık iki hafta gecikmiști. İkinci olguya ise birinci olgudan kazanilan tecrübe ile tanı hemen konmuş ve tedavide herhangi bir gecikme yașanmamıștı. Her iki olgunun da Brucella

\section{ABSTRACT}

Brucellosis is a zoonotic infectious disease caused by Brucella species, still endemic in our country affecting different organs and systems. Mainly it is transmitted by direct contact with an infected animal, unpasteurized milk and milk products from infected animals, and to laboratory personnel working with these bacteriae by direct contact or with aerosol inhalation. Therefore, beside livestock farmers and veterinarians, laboratory personnel are also under the risk of infection. Brucelossis is among the most common laboratory acquired infectious diseases in the world. However, laboratory acquired brucelossis cases are rarely reported in our country. In this report, two cases of laboratory acquired brucelossis in two microbiology laboratory personnel are presented. Both of the patients were female, presenting with fever, muscle and joint pain and no other findings on physical examination. Their hemogram and biochemistry parameters were within normal ranges, and their common feature was working with Brucella species bacteriae. The first patient was initially evaluated as viral infection and the final diagnosis was delayed for approximately two weeks. The second patient however, was diagnosed and treated on time based on our experience with the first patient. Both patients had postivie Brucella tube agglutination tests $1 / 1280$ and $1 / 640$ respectively and

Süleyman Demirel Üniversitesi, Tıp Fakültesi, Enfeksiyon Hastalıkları Ana Bilim Dalı, ISPARTA

${ }^{2}$ Muğla Üniversitesi, Tıp Fakültesi, Enfeksiyon Hastalıkları Ana Bilim Dalı, MUĞLA

İletişim/Corresponding Author : İbak GÖNEN Süleyman Demirel Üniversitesi, Tıp Fakültesi, Enfeksiyon Hastalıkları Ana Bilim Dalı, ISPARTA

Tel : +902462119324

E-posta /E-mail :dribak77@hotmail.com

DOI ID : 10.5505/TurkHijyen.2014.37132

Gönen I, Kaya O, Sözen H. Laboratory acquired brucellosis: a report of two cases. Turk Hij Den Biyol Derg, 2014; 71(3): 141-6. 
tüp aglutinasyon testleri sırası ile 1 / 1280 ve 1 / 640 olarak pozitif saptanmıș ve kan kültürlerinde Brucella türü bakteri izole edilmiștir. Olgular doksisiklin $(2 \mathrm{x}$ $100 \mathrm{mg}$ ) ve rifampisin ( 1 x $600 \mathrm{mg}$ ) verilerek başarılı bir şekilde tedavi edilmiştir. Sonuç olarak, bu iki olguyla brusellozun laboratuvar ortamında bulașabileceği, bulașı engellemek için personel koruyucu ekipman kullanımının arttırılması gerektiği ve klinisyenlerin ateș şikayeti ile bașvuran laboratuvar çalıșanlarında laboratuvardan kazanılmış brusellozu araștırmaları gerektiği unutulmamalıdır.

Anahtar Kelimeler: Bruselloz, laboratuvar kaynaklı enfeksiyon
Brucella species microorganisms were isolated in the blood cultures. The patients were successfully treated with doxycicline $(2 \times 100 \mathrm{mg})$ and rifampicin ( 1 X 600mg). As a result, we would like to remind that brucellosis might be transmited in the laboratory environment and in order to prevent the contamination the personnel must comply with the use of protective equipment. As for the clinicians, they should consider investigating brucellosis in laboratory personel presenting with fever.

Key Words: Brucellosis, laboratory acquired infection

\section{INTRODUCTION}

Brucellosis is a zoonotic infectious disease, caused by bacteria of Brucella species, which is still endemic in our country, and can induce various clinical symptoms and signs due to its ability to affect different organs and systems. Beside the fact that it spreads essentially from contaminated milk and dairy products, it can also be transmitted from direct contact with infected animals and their body fluids, or inhalation of aerosols containing bacteria (1). Thereby, occupational risk groups are composed of those who are involved in animal husbandry, veterinarians, and laboratory personnel. In this paper, we report two cases of laboratory-acquired brucellosis.

Case 1: A 26-year-old female patient who works in a microbiology laboratory was admitted to our polyclinic with complaints of high fever, malaise, and severe pain in the muscles and joints. In the physical examination, body temperature, arterial blood pressure, heart rate and respiratory rate were found to be $38.6^{\circ} \mathrm{C}, 110 / 70 \mathrm{~mm} / \mathrm{hg}, 88 \mathrm{bpm}$ and $14 /$ min, respectively. Systemic physical examination was normal except for high fever. No abnormalities in haemogram and biochemical parameters were encountered in laboratory examination. Symptomatic treatment was applied, considering a viral infection. However, in addition to the fact that no symptomatic improvement was seen in the patient within 10 days, the complaints of muscular and joint pain deteriorated progressively. When the patient's history was further examined in the second admission, it was yielded that the patient was injured by the hand with a contaminated injector needle while passing a tube containing positive blood culture, and the bacteria was reported to be Brucella abortus. Ignoring this injury, the patient expressed that she was not admitted to any department. Brucella tube agglutination test was positive with 1/1280, and Brucella abortus was isolated from blood cultures, and rifampicin $(1 \times 600 \mathrm{mg})$ and doxycycline $(2 \times 100 \mathrm{mg})$ was started orally after diagnosis of brucellosis. On the fifth day of treatment, there was a significant improvement in the symptoms of the patient whose fever had decreased markedly. No complication was observed throughout the treatment process continued for 45 days. 
Case 2: A 32-year-old female patient who works in a microbiology laboratory was admitted to polyclinics of infectious diseases with complaints of high fever, malaise, and wide-spread bodily pain. Body temperature, arterial blood pressure, heart rate and respiratory rate were $38.9^{\circ} \mathrm{C}, 120 / 70$ $\mathrm{mmHg}, 104 / \mathrm{min}$ and $18 / \mathrm{min}$, respectively. No pathological physical examination findings other than high fever were found. WBC, CRP and ESR were detected to be 11.200 (80\% polymorphonuclear leukocytes), $12.3 \mathrm{mg} / \mathrm{dL}$ and $45 \mathrm{~mm} / \mathrm{hr}$, respectively. Based on our experiences with the former case, when the patient's history was further examined, it was elicited that the patient had performed such works as seeding bacteria of Brucella sp. onto culture medium, antibiogram, and typing in a microbiology laboratory in the last month. It was noted that protective precautions like gloves and masks were not taken during these procedures. The patient was carrying no other risk factors, in terms of brucellosis, such as consuming milk and dairy products other than the former procedures. The Brucella tube agglutination test was positive with $1 / 640$, Brucella melitensis was isolated from blood cultures. Brucella species were identified according to oxidase testing, urease positivity, $\mathrm{H}_{2} \mathrm{~S}$ production, $\mathrm{CO}_{2}$ requerements, and dye sensitivity (basic fuchsin and thionine). The patient was started on rifampicin (1 x $600 \mathrm{mg})$ and doxycycline $(2 \times 100 \mathrm{mg})$ after the diagnosis of brucellosis. The patient's condition improved and the treatment was completed after 45 days.

\section{DISCUSSION}

Many microorganisms can produce laboratoryacquired infection. Brucellosis is one of the most encountered laboratory-acquired bacterial infections $(2,3)$. Brucellosis can be transmitted to laboratory personnel through inhalation or direct contact. Brucellosis cases were reported not only in countries where brucellosis is rampant, but in countries where brucellosis is seldom encountered as well. In a retrospective study comprising 1.240 clinical microbiology personnel in Spain, 75 of the personnel were detected to have had a Brucella infection (4). Moreover, between 1991 and 2000, Brucella infection occurred in seven healthcare personnel, one of which was a pathologist and the other six bacteriologists, in Saudi Arabia where the infection is endemic (5). Of the laboratory staff, microbiologists from U.S.A were reported to be infected by Brucella bacteria, as well (Table 1) (6).

Brucellosis is still endemic in our country and the annual incidence of the disease is 23 per 100,000 (7). Therefore, the laboratory personnel working with these bacteria are under the risk of contamination. However, laboratory acquired brucellosis cases are rarely reported in our country (8-11). In a multicenter survey with broad participation performed in our country, most important risk factors in acquiring brucellosis were being male, working directly with Brucella bacteria and low compliance of the laboratory personnel with the use of protective equipment and biosafety cabinets (12). Education of the healthcare personnel concerning transmission ways of brucellosis has also been emphasized. Again, in a study performed in our country on healthcare personnel working with Brucella species bacteria without applying level 3 biosafety precautions 12 healthcare personnel were detected to be infected with brucellosis (13).

Brucella bacteria can be transmitted to healthcare personnel in a laboratory environment via both inhalation and percutaneous route (14, 15). The group at highest risk is composed of those microbiologists and technicians working in the laboratories where blood cultures are seeded, and the examinations required are performed by passing cell lines to culture medium. Therefore, healthcare 
personnel must follow standard precautions, such as wearing gloves and masks, and they must utilize biosafety cabinets when working with bacteria. The risk of transmission to healthcare personnel working with Brucella bacteria can be minimized by applying these measures. If suspicious contact occurred beside the measures, risk identification should be performed and prophylactic antibiotic treatment should be started. Expert opinions on the post-exposure antibiotic treatment are present.
Antibiotic prophylaxis and surveillance procedures after exposure to Brucella bacteria according to risk groups recommended by the CDC (Centers for Disease Control and Prevention) are presented on Table 1. It should also be kept in mind that antibiotic side effects may occur. Related lethal side effects have also been reported (16). Therefore, risk classification should be performed and antibiotic prophylaxis should not be given unless required.

Table 1. Recommendations for surveillance and postexposure prophylaxis (PEP) after laboratory exposure to Brucella isolates (6).

\section{Evaluate all workers exposed to Brucella isolates and classify exposures as either high risk or low risk.}

Recommendation Prophylactic Therapy
PEP should be offered as soon as Brucella exposure has been identified, up to the end of the 6-month incubation period.
* Administer doxycycline $100 \mathrm{mg}$ twice daily and rifampin $600 \mathrm{mg}$ once daily for 3 weeks or doxycycline

* Trimethoprim-sulfamethoxazole (160 mg/800 mg) should be considered for patients with contraindications to doxycycline.

* Pregnant workers with high-risk exposures should be considered for PEP in consultation with their obstetricians. such work (eg, across an open bench top or within 5 feet), or

3) presence in the laboratory during any procedure conducted on a Brucella isolate that might result in generation of aerosolized organisms and inhalational exposure (eg, vortexing or catalase testing).

A low-risk exposure is defined as being present in the laboratory during an exposure but not meeting the definition for a high-risk exposure.
Discuss potential PEP with workers who have low-risk exposures to Brucella isolates.
* Obtain baseline serum samples from all workers exposed to Brucella sp.

* Arrange for serologic testing on all workers exposed to Brucella sp. (eg, 2, 4, 6, and 24 weeks postexposure) using agglutination testing (eg, tube or Brucella microagglutination testing)

* Arrange for regular (eg, weekly) active surveillance for febrile illness among all workers exposed to Brucella isolates for 6 months after last exposure. 
In conclusion, it is very important to educate the healthcare personnel working in the presence of Brucella species of the transmission pathways, to provide the use of protective equipment and biosafety cabinets, and to increase the compliance with infection control measures in order to prevent laboratory acquired brucellosis in endemic countries such as ours. In case of contact, risk classification should be performed and antibiotic prophylaxis started. Beside this, it is also important for clinicians to evaluate those admitted with such complaints as high fever, and muscular and joint pains for brucellosis in terms of earlier diagnosis, and prevention of possible complications.

\section{REFERENCES}

1. Young EJ. Brucella species. In: Mandell GL, Dolin $\mathrm{R}$, Bennett JE, eds. Principles and practice of infectious diseases. 6th ed. Philadelphia. Elsevier Churchill Livingstone, 2005: 669-74.

2. Singh K. Laboratory-acquired infections. Clin Infect Dis, 2009; 49 (1): 142-7.

3. Sewell DL. Labortaory ascociated infections and biosafety. Clin Microbiol Rev, 1995; 8 (3): 389-405.

4. Bouza E, Sanchez-Carrillo C, Hernangomez S, Gonzalez MJ. Spanish co-operative group for the study of laboratory-acquired brucellosis. Laboratory-acquired brucellosis: a Spanish national survey. J Hosp Infect, 2005; 61 (1): 80-3.

5. Memish ZA, Mah MW. Brucellosis in laboratory workers at a Saudi Arabian hospital. Am J Infect Control, 2001; 29 (1): 48-52.

6. Anonymous. Centers for Disease Control and Prevention (CDC). Laboratory-acquired brucellosis-Indiana and Minnesota, 2006. MMWR Morb Mortal Wkly Rep, 2008 ; 57 (2): 39-42.

7. Anonymous. Republic of Turkey, Ministry of Health, brucellosis statistical data for 1970-2004.
8. Sengöz G, Yasar KK, Yıldırım F, Berzeg D, Altay G, Nazlıcan Ö. Laboratory acquired brucellosis: a case report. Türk Mikrobiyol Cem Derg, 2006; 36 (1): 40-3.

9. Demirdal T, Demirtürk N. Laboratory-acquired brucellosis. Ann Acad Med Singapore, 2008; 37 (1): 86-7.

10. Ozaras R, Celik AD, Demirel A. Acute hepatitis due to brucellosis in a laboratory technician. Eur J Intern Med, 2004; 15 (4): 264.

11. Karakaș A, Mert G, Coșkun Ö, Alga ÖH, Beșirbellioğlu BA, Eyigün CP. S 19 hayvan aşısının kazayla inokülasyonu sonrası gelișmiș bir bruselloz olgusu. Turk Hij Den Biyol Derg, 2012; 69 (1): 37-40.

12. Sayın-Kutlu S, Kutlu M, Ergonul O, Akalın S, Guven T, Demiroglu YZ, et al. Occupational infectious diseaes study group. Laboratory-acquired brucellosis in Turkey. J Hosp Infect, 2012; 80 (4): 326-30.

13. Ergönül Ö, Çelikbaș A, Tezern D, Güvener E, Dokuzoğuz B. Analysis of risk factors for laboratory-acquired Brucella infections. J Hosp Infect, 2004; 56 (3): 223-7. 
14. Maley MW, Kociuba K, Chan RC. Prevention of laboratory- acquired brucellosis: significant side effects of prophylaxis. Clin Infect Dis, 2006; 42 (3): 433-4.

15. Staszkiewicz J, Lewis CM, Colville J, Zervos M, Band J. Outbreak of Brucella melitensis among microbiology laboratory workers in a community hospital. J Clin Microbiol, 1991; 29 (2): 287-90.
16. Fiori PL, Mastrandrea S, Rappelli P, Cappuccinelli P. Brucella abortus infection acquired in microbiology laboratories. J Clin Microbiol, 2000; 38 (5): 2005-6. 